\title{
Phytoplankton in a Temperate-Zone Salt Marsh: Net Production and Exchanges with Coastal Waters*
}

\author{
R.A. Moll \\ Department of Biology, Brookhaven National Laboratory; Upton, New York, USA and \\ Marine Biology Program, Department of Ecology and Evolution, State University of New York at Stony Brook; Stony Brook, USA
}

\begin{abstract}
Phytoplankton production and associated variables were measured in Flax Pond, a 52 ha salt marsh on the north shore of Long Island, New York, from July 1972 to october 1973. Measurements made up to five times per day, once per week, yielded a mean annual net primary production, determined by the ${ }^{14} \mathrm{C}$ technique, of 20.5 $\mathrm{mg} \mathrm{c} / \mathrm{m}^{3} / \mathrm{h}$; daily means were as high as $60.0 \mathrm{mg} \mathrm{c} / \mathrm{m}^{3} / \mathrm{h}$. However, when productivity was calculated for the entire marsh ecosystem, the shallow water in the salt marsh produced only $11.7 \mathrm{~g} \mathrm{c} / \mathrm{m}^{2}$ of marsh/year. There was a net flux of phytoplankton

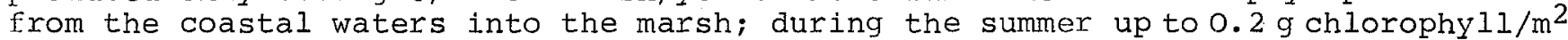
of marsh was carried in with the tides daily and remained in the marsh. Analysis of the productivity data, as well as variables associated with productivity (pH, standing crop, nutrients, extinction coefficient), indicated that the aquatic portion of the marsh behaved more as a net consumer rather than a net producer of phytoplankton.
\end{abstract}

\section{Introduction}

The importance of production by phytoplankton in salt marsh systems has been poorly understood and difficult to quantify. Measurements of primary productivity in a system where the basic populations are transient has proven difficult, and not surprisingly results have not concurred (Ragotskie, 1959; Schelske and Odum, 1961; Teal, 1962; Williams, 1966; Qasim et al., 1969). While some studies have recorded negative net phytoplankton production in intertidal areas (Ragotskie, 1959), other studies have recorded high production (Schelske and odum, 1961). A review of salt marsh literature (Woodwell et al., 1973) showed that geographical location of the salt marsh, type of marsh (drowned river mouth, delta, etc.), extent of spartina spp. flats, and height of tide were all factors which caused great variation in phytoplankton production.

A good study of phytoplankton production in salt marshes has eluded researchers, in part, because of the dynamic

\footnotetext{
* $_{\text {Research }}$ carried out at Brookhaven National Laboratory, supported by the U.S. Atomic Energy Commission and the National Science Foundation under Grant No. AG-375.
}

nature of the ecosystem. Strong tides flooding the marsh once or twice per day bring in water with a potentially new chemical, physical, and biological regime (Odum, 1971). Once the flooding waters have entered a marsh system, biological metabolism within the marsh and freshwater runoff serve to quickly alter the characteristics of the recent incoming tide. The study of phytoplankton within the salt marsh is further compounded by the numerous measurements necessary to quantify a dynamic system. Measurements of production and related variables are necessary on a temporal and spatial scale; samples should be taken weekly to measure seasonal variation, as well as throughout the day and in different locations to investigate small-scale spatial and temporal variations within the marsh.

\section{The Study Area}

In 1972 a study of phytoplankton in Flax Pond, a Long Island, New York, salt marsh was begun. This marsh is small (about 50 ha) with a drainage basin only slightly larger than the marsh itself. The small, sandy drainage basin did not produce any noticeable freshwater runoff 
(Woodwell and Pecan, 1973). A well equipped New York State Conservation Laboratory is located directly on the edge of the marsh, providing a site for marshside sample processing, as well as a site for a small, continuously recording weather station.

Flax Pond is a temperate salt marsh, dominated by two tides per day averaging $1.8 \mathrm{~m}$ in amplitude. Approximately $80 \%$ of the volume of water in the marsh is exchanged with each tide. Annual water temperatures range from -1.50 to $290^{\circ}$. The ecosystem is dominated by spartina alterniflora, with some stands of $S$. patens. The history of the marsh and some salient points of hydrology and chemistry have been described by woodwell and Pecan (1973).

The marsh was the focus of an intense investigation carried out by Brookhaven National Laboratory from 1971 to 1974. Included in this ecosystem study were: exchanges of nutrients between the marsh and the nearshore aquatic environment, carbon budgets, and sedimentation rates (Armentano and Woodwell, 1975; Whitney et al., 1975; Woodwell et al., 1975). These data provided an exceptional supplement to the phytoplankton study.

\section{Materials and Methods}

\section{Sampling Regime}

Samples were collected from three locations in the salt marsh shown in Fig. 1. one was in a shallow channel which drained a small area of marsh flats (A), the second was in a deep pond-like area which contained most of the residual water in the marsh at low tide (B), and the third was in a shallow channel which drained an extensive area of spartina spp. flats (C).

Samples were collected in a plastic Van Dorn bottle cast from a flat-bottom boat powered by an air motor. The air motor was needed to sample shallow stations without disturbing soft-bottom sediments. Replicate casts were made at two of the three sampling locations. Measurements of submarine light and water temperature were made at every station. The water in the Van Dorn bottle was immediately split into fractions appropriate for analysis: $100 \mathrm{ml}$ were placed in a small plastic bottle with 1 to $2 \mathrm{ml}$ of Lugol's iodine for phytoplankton cell counts, 11 was placed in a dark bottle for filtering in the lab, $250 \mathrm{ml}$ were placed in a darkened bottle for nitrogen analysis, and the remaining water was used for ${ }^{1}{ }^{C} \mathrm{C}$ productivity determinations.

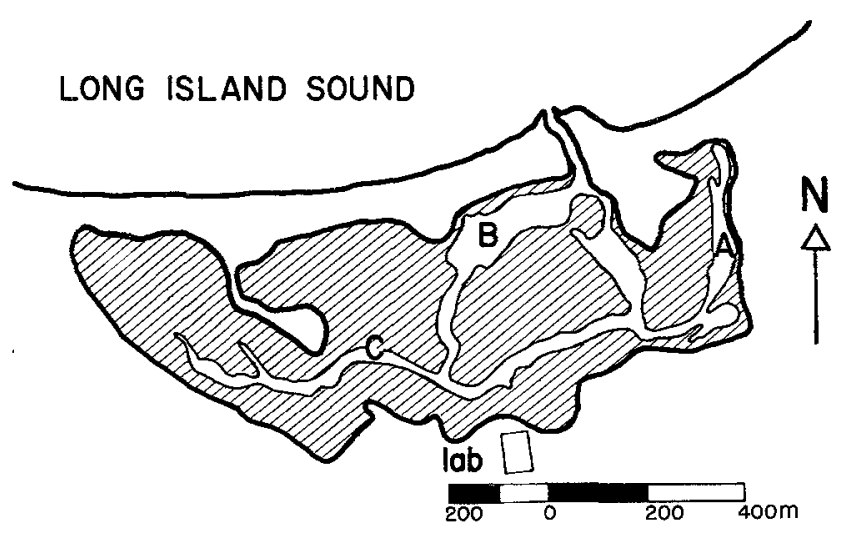

Fig. 1. Three sampling stations in Flax Pond ( $A$, $B$, C). Also shown on the map are spartina spp. flats (shading) and the New York State Conservation Laboratory

Samples were collected on an everyother-hour basis one day per week. Samples were taken in the period from just after sunrise (first hour of the day) to just before sunset (last hour of the day).

${ }^{14} \mathrm{C}$ Technique

Productivity estimates were made with the $14 \mathrm{C}$ technique (Steemann Nielsen, 1952) using modifications to correct for dissolved loss (Hall and Moll, 1975). Samples were incubated in situ at depths from which they were collected (usually from 0.25 to $2 \mathrm{~m}$ depth); three $125 \mathrm{ml}$ bottles made up one incubation set consisting of two light bottles and one dark bottle. Each bottle was inoculated with from 1 to $4 \mu \mathrm{Ci}$, depending on expected productivity. Care was taken not to light-shock phytoplankton while they were being lowered to incubation depths. Incubation periods were purposely kept short to prevent excessive bacterial growth (Lewis, 1974) and ranged from $1 \frac{1}{2}$ to $3 \mathrm{~h}$. Each series of incubations was terminated by placing the bottles in a dark box and filtering the samples through HA Miliipore filters $(0.45 \mu)$ as quickly as possible. After the filters appeared dry, they were fumed over HCl. Dissolved release of incorporated $1^{14} \mathrm{C}$ was measured by acidifying a small vial of filtrate with dilute $\mathrm{H}_{3} \mathrm{PO}_{4}$ (to approximately $\mathrm{pH} 3.0$ to 3.5 ), and bubbling $\mathrm{N}_{2}$ gas through the sample for $5 \mathrm{~min}$. Samples were counted on a scintillation counter and were corrected for quenching by channels ratio and external standards.

\section{Physical and Chemical Data Collection}

Surface sunlight intensities at Flax Pond were continuously recorded by a 


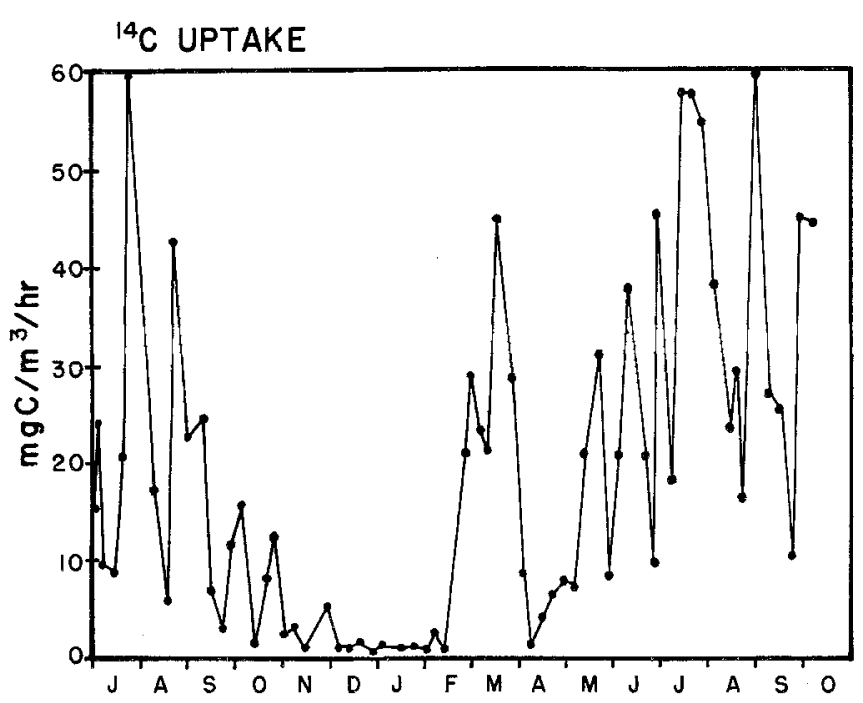

Fig. 2. ${ }^{14} \mathrm{C}$ uptake for sampling period, July 1972 to october 1973. Each point is mean of 1 week's observations

thermopile located at the edge of the marsh on the roof of the New York State Conservation Laboratory. These light readings, provided by the general research effort of Brookhaven National Laboratory, were recorded throughout the entire 16-month sampling period. Submarine light readings were made at all stations by a calibrated submarine photometer. This photometer, fashioned after the description of Rich and Wetzel (1969), provided readings in $\mathrm{g} \mathrm{cal} / \mathrm{cm}^{2} / \mathrm{min}$ for both downwelling and upwelling light.

Water samples for nitrate and nitrite were placed, unfiltered, in clean $250 \mathrm{ml}$ plastic bottles and refrigerated within $1 \mathrm{~h}$ of collection. Refrigerated samples were then frozen no more than $12 \mathrm{~h}$ after collection and kept frozen until determinations were made, usually 1 day after collection. Nitrate-nitrogen levels were measured by the procedure of Strickland and Parsons (1972), cadmium reducing columns and azo dye. Levels of other important nutrients in the salt marsh were measured as part of the Brookhaven Laboratory sampling program (Whitney et al., 1975; Woodwell et al., 1975). Nutrients included in these measurements were: $\mathrm{NH}_{3}$, $\mathrm{SiO}_{4}$, total-PO4, and soluble-- $\mathrm{PO}_{4}$.

Chlorophyll values were determined by a procedure that was modified from conventional grinding techniques. Up to $500 \mathrm{ml}$ of water was passed through a GF/C filter which had been pretreated with $2 \mathrm{mI}$ of $1 \% \mathrm{MgCO}_{3}$ solution. Two methods of extraction with $80 \%$ acetone were used, grinding and sonification. Both methods gave comparable results, although the sonification method yielded slightly higher levels of extraction (about 3 to $4 \%$ higher). All extraction procedures were carried out under a green (530 nm) light and every effort was made to keep extracted samples cool. The grinding procedure was basically the one described by SCOR-UNESCO (1969). Extinctions were read using $10 \mathrm{~cm}$ cells from 750 to $480 \mathrm{~nm}$ on a Carey model $14 \mathrm{R}$ spectrophotometer. Spectrophotometric determinations of chlorophyll appeared better than fluorometric determinations as estuarine waters often have an abundance of non-chlorophyll fluorescing materials (Strickland and Parsons, 1972). Chlorophylls $a, b, c$, and plant pigment concentrations were calculated by the Strickland and Parsons equations, although only the chlorophyll $a$ and plant pigment values were assumed valid.

\section{Results and Discussion}

In Situ ${ }^{14} \mathrm{C}$ uptake

The results of the 16 months of ${ }^{14} \mathrm{C}$ incubations showed relatively high uptake rates in Flax Pond. Fig. 2 shows the weekly means of carbon uptake (particulate plus dissolved) throughout the entire period; some weekly means were as high as $60 \mathrm{mg} \mathrm{C} / \mathrm{m}^{3} / \mathrm{h}$, with individual incubations exceeding $150 \mathrm{mg} \mathrm{c} / \mathrm{m}^{3} / \mathrm{h}$.

The annual cycle of production showed a spring diatom bloom which began in late February of 1973, culminated in midMarch, and died back rapidly to prebloom conditions in early April (Fig. 2). At the peak of the spring bloom the daily mean of carbon uptake exceeded $45 \mathrm{mg}$ $\mathrm{C} / \mathrm{m}^{3} / \mathrm{h}$. Productivity remained low following the spring bloom (less than $10 \mathrm{mg}$ $\mathrm{C} / \mathrm{m}^{3} / \mathrm{h}$ ) until mid-May, when summer growth began. Productivity values consistently exceeded $50 \mathrm{mg} \mathrm{C} / \mathrm{m}^{3} / \mathrm{h}$ by midJune in 1972 and 1973. Crop assemblages shifted from diatom dominated to dinoflagellate dominated by late summer. Table 1 shows the major species components by season observed in the salt marsh, while Moll (1974) gives a more complete description of the plankton observed in the marsh. Production during the summer periods remained high (weekly means exceeding 30 to $40 \mathrm{mg} \mathrm{C} / \mathrm{m}^{3} / \mathrm{h}$ ) until middle August, when productivity slowly tapered, reaching winter levels by late october or early November. In 1972 and 1973 a fall bloom was readily observed by a shift in species composition (from a dinoflagel late dominated community to a Skeletonema costatum dominated community) and an increase in cell numbers. The fall bloom yielded moderately high levels of productivity, although not as high as either the summer growth period, or the spring bloom. Winter productivity 
Table 1. Associations of common species of phytoplankton in Flax Pond. Thin lines represent species consistently present in samples, while heavy lines represent dominant species (species which compose more than $5 \%$ of total number of cells in samples)

Common species
Skeletonema costatum
Cerataulina pelagica
Ceratium fusus
Chaetoceros compressum
Thalassiosira decipiens
Thalassionema nitzschioides
Navicula spp.
Rhizosolenia fragillissima
Leptoculindricus danicus
Asterionella japonica
Peridinium trochiodeum
Coscinodiscus radiatus
Exuviella apora
Chaetoceros debile
Chaetoceros radians
Nitzschia longissima
Prorocentrum scutellum
Eucampia zoodiacus
Pleurosigma spp.
Chaetoceros curvisetus
Thalassiosira gravida
Distephanus speculum

Table 2. Data from August 29, 1972. Each estimate was mean of 1 or more observations. Number of observations is shown in parentheses

\begin{tabular}{|c|c|c|c|}
\hline $\begin{array}{l}\text { Sampling } \\
\text { locationa }^{2}\end{array}$ & $\begin{array}{l}\text { Chlorophyl1 } \\
(\mu \mathrm{g} / 1)\end{array}$ & $\begin{array}{l}{ }^{14 \mathrm{C} \text { uptake }} \\
(\mu \mathrm{g} \mathrm{C} / \mathrm{I} / \mathrm{h})\end{array}$ & $\begin{array}{l}\text { Phytoplankton } \\
\text { (celis/I) }\end{array}$ \\
\hline$A-1$ & $2.50 \quad(2)$ & $9.80(4)$ & $1.410 \times 10^{5}(2)$ \\
\hline$B-1$ & $3.26 \quad(2)$ & $5.23 \quad(4)$ & $8.011 \times 104$ (2) \\
\hline$c-1$ & 14.55 (1) & $7.85 \quad(2)$ & $3.128 \times 10^{5}$ (1) \\
\hline$A-2$ & $8.39(2)$ & $62.28 \quad(4)$ & $6.529 \times 10^{5}(2)$ \\
\hline$B-2$ & $2.26 \quad(2)$ & 16.18 (4) & $8.402 \times 10^{4}(2)$ \\
\hline$c-2$ & 3.10 (1) & 16.65 & $1.409 \times 10^{5}$ (1) \\
\hline$A-3$ & $6.04 \quad(2)$ & $28.73 \quad(4)$ & $1.290 \times 10^{5}(2)$ \\
\hline$B-3$ & $5.29 \quad(2)$ & $23.45 \quad(4)$ & $1.055 \times 10^{5}(2)$ \\
\hline$c-3$ & 5.71 (1) & $22.45 \quad(2)$ & $1.170 \times 10^{5}$ (1) \\
\hline
\end{tabular}

aetters define sampling locations in Fig. 1, numbers indicate mid-morning, midday, and mid-afternoon samples $(1,2,3$, respectively)

values (less than $7 \mathrm{mg} \mathrm{c} / \mathrm{m}^{3} / \mathrm{h}$ ) were observed from mid-November through to the onset of the spring bloom.

Variation in $14 \mathrm{C}$ uptake on a less than annual basis (within one sampling date or between sampling stations) was more difficult to analyze than week-toweek variation. Patchiness of phytoplankton produced production estimates which varied as much as $60 \%$ between two sta- tions sampled within $20 \mathrm{~min}$ of one another. Table 2 shows data from August 1972 where patchiness was evident in the chlorophyll, ${ }^{4} \mathrm{C}$ uptake, and cell count data. Daily averages for any of the three variables were a good estimate of the sample mean $(n=15)$, but individual station estimates were not as good because of the small sample size $(n=2)$. These results indicated that a different experimental design was needed to more adequately quantify $14 \mathrm{C}$ uptake on a less than daily basis.

Separation of total ${ }^{14} \mathrm{C}$ uptake into dissolved and particulate fractions showed that dissolved loss accounted for only a small part of total $14 \mathrm{C}$ uptake. occasional estimates showed dissolved loss accounting for $15 \%$ of total uptake, but the annual average was only $2 \%$.

The initial conclusion to these productivity estimates was that the fixation of carbon by phytoplankton in the salt marsh contributed significantly to the carbon pool of the marsh. However, the values reported above all were in terms of $\mathrm{mg} \mathrm{C} / \mathrm{m}^{3} / \mathrm{h}$, and must be converted to $\mathrm{mg} \mathrm{c} / \mathrm{m}^{2} /$ day. Conversion of the carbon fixation values to carbon fixed per square meter required a different approach for Flax Pond than for open waters. The solution was approached by finding the carbon fixed on a marsh-wide 
basis directly, rather than finding production per square meter and converting this to production for the whole marsh. The basic approach consisted of averaging ${ }^{14} \mathrm{C}$ uptake values for the whole marsh, calculating uptake from surface to bottom, considering submarine light extinction, and expanding this estimate of ${ }^{14} \mathrm{C}$ uptake to the entire column of water in the marsh. This procedure was repeated every time a new measure of $14 \mathrm{C}$ uptake was made (once every other hour) until a daily estimate of carbon fixed per marsh was obtained.

\section{Estimates of Production on a Marsh-Wide Basis}

In Flax Pond, tides bringing water from Long Island Sound twice daily constantly changed the size and composition of the plankton crop, levels of dissolved nutrients, water depth, etc. Any one measure of photosynthesis was a good estimate of productivity for surrounding waters for a short period of time (no more than a few hours). Obtaining an estimate of marsh-wide production involved consideration of many variables including the extinction coefficient and tide height. Tide height influenced photosynthesis by increasing or decreasing the amount of water in the marsh. Changes in the tide induced changes in the extinction coefficient by washing debris from the mud flats into the water column. These considerations led to the development of an equation to predict photosynthesis by phytoplankton in Flax Pond with the use of multiple linear regression and calculus.

A stochastic prediction of photosynthesis was developed with the use of productivity and related variables measured simultaneously 298 times. An equation using water temperature, chlorophyll concentrations, dissolved inorganic nitratenitrogen levels (Fig. 3), and submarine light intensities yielded a good prediction of primary production. All variables were transformed by natural logs to correct skewed distributions (Sokal and Rohlf, 1969). The equation was:

$$
\begin{aligned}
\ln (C \text { fixed })= & -0.8265-0.0649[\ln (\mathrm{N})] \\
& +0.8544[\ln (\mathrm{C})]+0.2504 \\
& {[\ln (\mathrm{L})]+0.4933[\ln (\mathrm{W})] . }
\end{aligned}
$$

where $C$ fixed = carbon fixed (mg) of total production per cubic meter per hour (net $14 \mathrm{C}$ production); $\mathrm{N}=$ nitrate-nitrogen concentration in $\mu g \mathrm{~N} / \mathrm{l} ; \mathrm{C}=$ chlorophyll concentrations in $\mu g / 1 ; W=$ water temperature in ${ }^{\circ} \mathrm{C} ; \mathrm{I}=$ submarine light intensity in $\mathrm{g} \mathrm{cal} \mathrm{cm}^{2} \mathrm{~min}^{-1}$. The large number of observations produced a low standard error of the predicted mean

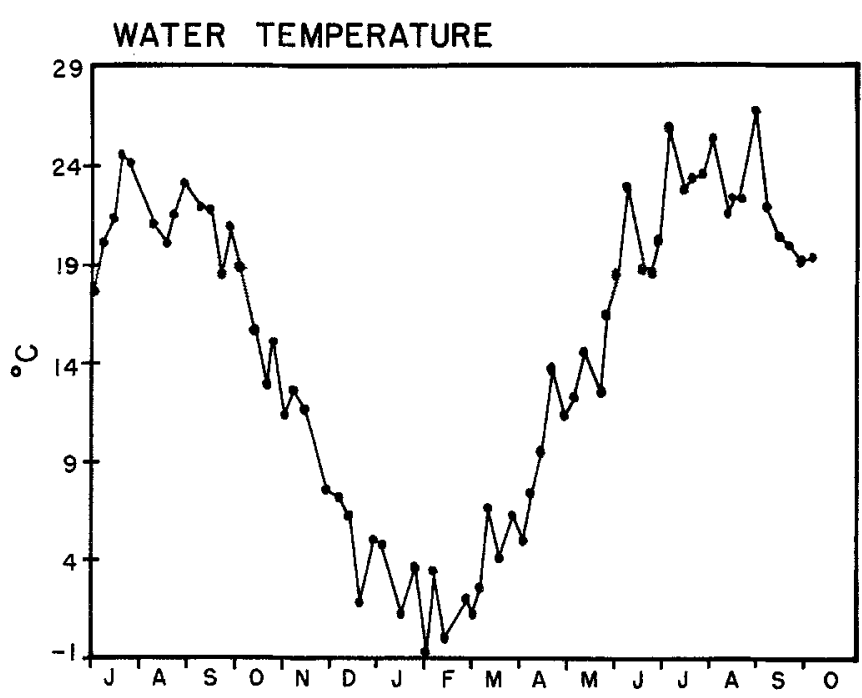

CHLOROPHYLL A
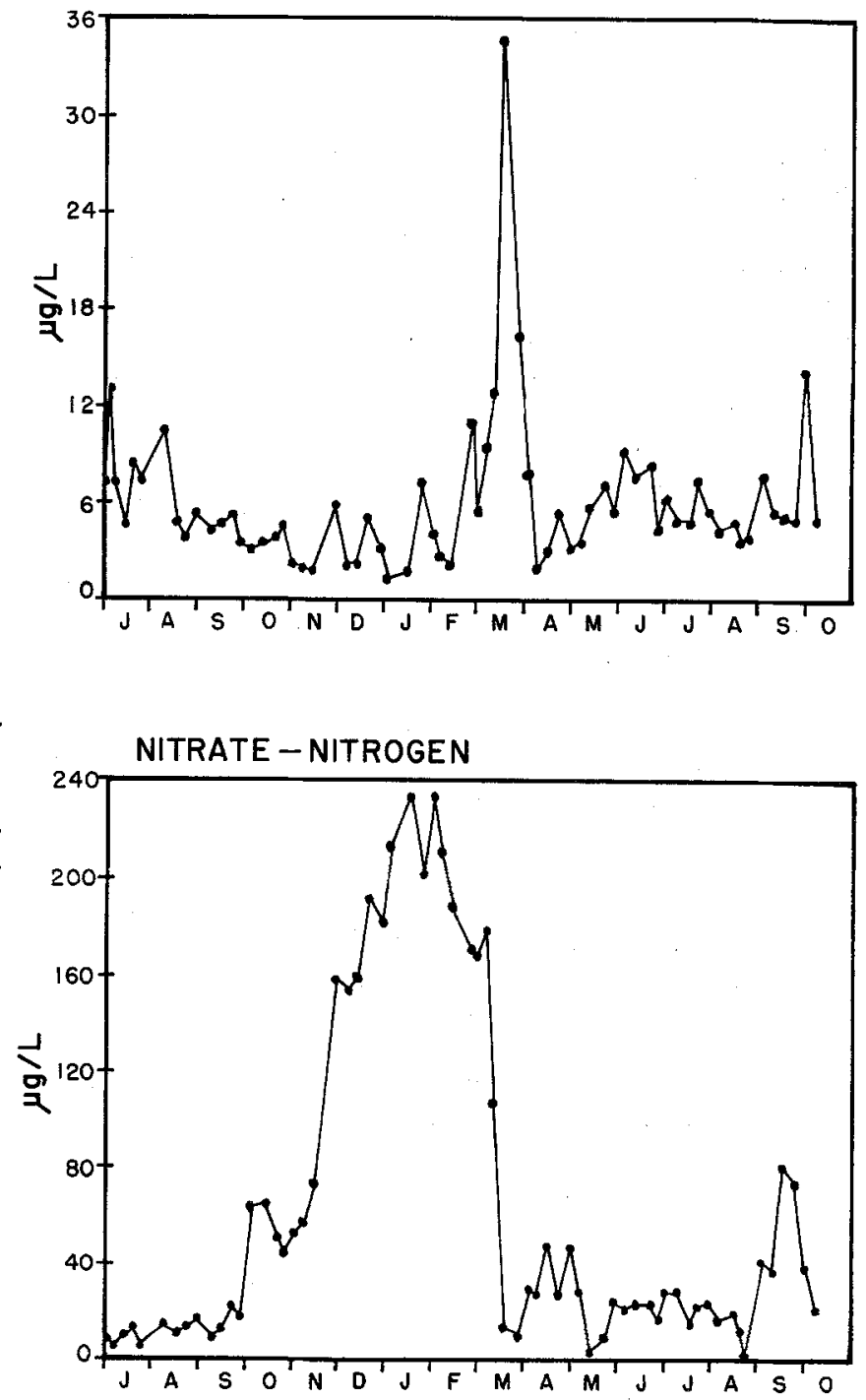

Fig. 3. Water temperature, chlorophyll a concentrations, and nitrate-nitrogen concentrations for sampling period, July 1972 to October 1973. Each point is mean of 1 week's observations 


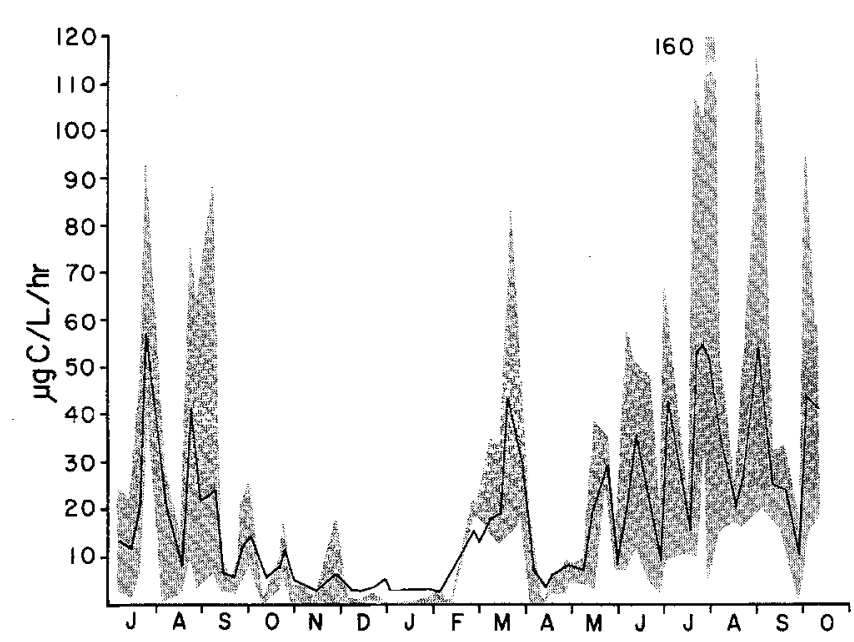

Fig. 4. Comparison of observed ${ }^{14} \mathrm{C}$ uptake to predict ${ }^{14} \mathrm{C}$ uptake for sampling period, July 1972 to October 1973. Line is the weekly prediction of ${ }^{14} \mathrm{C}$ uptake by the regression equation, while shaded area covers the range of weekly ${ }^{14} \mathrm{C}$ uptake values measured in the field

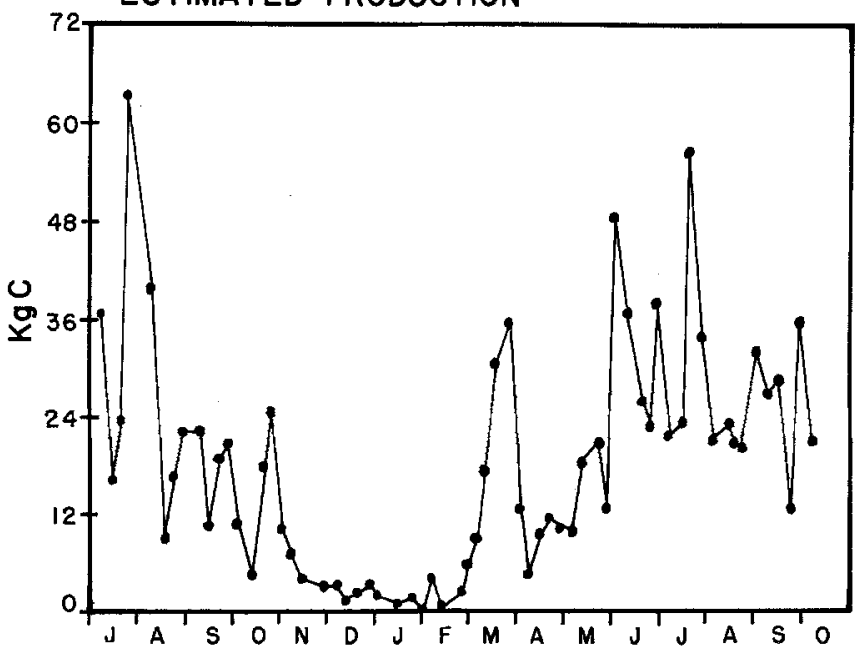

Fig. 5. Phytoplankton net production estimated for the marsh from July 1972 to October 1973. Each point, expressed as $\mathrm{kg} C$ fixed, is estimation of 1 day's production for entire marsh system

(about $\pm 2.0 \mathrm{mg} \mathrm{C} / \mathrm{m}^{3} / \mathrm{h}$ ) while yielding a high multiple correlation coefficient of 0.72 . Fig. 4 shows the ranges of $14 \mathrm{C}$ uptake observed in the salt marsh and the daily means of $14 \mathrm{C}$ uptake as predicted by the regression equation. The fit was good in that very few predicted means fell outside the observed ranges.

An advantage of the development of a multiple regression equation was prediction of values (of the dependent variable) which were not measured in the field (Li, 1964). In this case, knowledge of submarine light values allowed prediction of photosynthesis for the entire water column. In practice, the estimation of photosynthesis for the water column was made as follows: readings of nitrate-nitrogen, chlorophyll, water temperature, and extinction coefficients were made at all three stations and averaged. Sunlight readings were recorded continuously at the surface of the water. Assuming chlorophyll, nitrogen, and water temperature were homogenous in a water column (an inaccurate but useful assumption), a prediction of photosynthesis was made from surface to bottom continuously readjusting submarine light intensity. One prediction was made for the marsh based on an average extinction coefficient from a set of measurements at all three stations. The first prediction of photosynthesis was made using a light value at $0.25 \mathrm{~m}$ below the surface. The next prediction was made using a light value $0.5 \mathrm{~m}$ below the surface. Continuing light value substitutions at $0.25 \mathrm{~m}$ intervals gave a prediction of photosynthesis from the surface to the bottom. The surface to bottom predic- tions of photosynthesis were for a $1 \mathrm{~m}^{2}$ water column. Adjustments were necessary to expand these predictions to the area of the salt marsh covered by water. These adjustments were made by the development of a functional relationship between tide height and volume of water within Flax Pond. Tide height was measured constantly during the entire sampling period.

These estimates of production were for the entire marsh from one set of observations. The independent variables in the equation were measured every other hour as a normal part of the sampling regime; these measurements, along with continuous measurements of solar radiation and tide height, allowed new predictions of primary production in the marsh every other hour. Multiplying the predictions (which were in terms of carbon fixed for the marsh for $1 \mathrm{~h}$ ) by the number of hours between samples expanded the prediction of photosynthesis for Flax Pond for 1 day. Repeating these calculations for each sampling date resulted in an annual budget of carbon fixed by phytoplankton based on once weekly observations. Multiplication of the once weekly marsh-wide production estimates for the day by 7 (days in a week) resulted in the final estimate of annual carbon fixed by phytoplankton.

Fig. 5 shows that phytoplankton within Flax Pond annually fixed $5.871 \times 10^{6} \mathrm{~g}$ of carbon for the year ending July 14 , 1973. This was $11.7 \mathrm{~g}$ carbon fixed per square meter of marsh surface per year (approximately $23.4 \mathrm{~g}$ dry organic matter). Although we found high production on a unit volume basis in Flax Pond, pro- 
duction of a $\mathrm{m}^{2}$ basis was much lower than found in Long Island Sound (Riley, 1956). A possible explanation for the low production was that Flax Pond salt marsh as a shallow water system had a very small volume of water for photosynthesis during much of the tidal cycle. Daily production values were affected if high tide occurred at noon, presenting a large volume of water for photosynthesis during the day; or in the early morning, presenting a small volume of water for photosynthesis during the day.

Analysis of Parameters Associated with Production

One advantage of multiple regression is the extrapolation of the predictive formula to conditions not measured during sampling ( $\mathrm{Li}, 1964)$. The regression equation was used to determine the difference in photosynthesis between cloudy and sunny days. All variables were left unchanged from their observed state, except surface radiation. Whenever samples were taken on a cloudy day, the sunlight values of the cloudy day were replaced with sunlight values of a sunny day occurring one or two days prior to or after the sampling date. The entire data set was reanalyzed using all sunny days, and marsh-wide photosynthesis repredicted. Table 3 compares the estimated production in Flax Pond with the different modifications made to each set of predictions.

The effect of high tide on marsh-wide production was investigated in a similar manner. All variables in the regression equation were left unchanged, while tide height data (used in the calculations of marsh-wide production, although not a variable in the predictive equation) were altered to simulate high tides occurring at midday. Under these conditions the maximum volume of water would be in Flax Pond during the hours of brightest sunlight. The combination of both sunny days and midday high tides produced predictions of a few very productive days, but basically the results showed little change from normal high tides and sunny days (Table 3 ).

One final set of predictions was made to simulate conditions near-shore in Long Island Sound. All variables were input to the predictive calculations in their original observed state. The area of the surface of the water column was made equivalent to the area of the surface in Flax Pond at high tide and the bottom was considered to be $15 \mathrm{~m}$ down. Productivity predictions were made using observed values of sunlight, extinction coefficient, nutrients, etc., from Flax Pond. These predictions showed that if conditions in Flax Pond prevailed in a water column in Long. Island Sound, primary production would have been high $\left(2.96 \times 10^{8} \mathrm{~g}\right.$ of carbon fixed per year for the entire area, or $593 \mathrm{~g} / \mathrm{m}^{2} /$ year).

These predictions for Flax Pond would have been better if there had been more reliance on empirical observations rather than predicted values. However, the quantity of empirical observations needed for a measure of marsh-wide photosynthesis without reliance on any predictive techniques would be prohibitive. The fact that the standard error of the predicted mean $(\bar{Y})$ was $1.052 \mathrm{mg} / \mathrm{m}^{3} / \mathrm{h}$ meant that a typical summer day estimate of marsh-wide photosynthesis was plus or minus $370 \mathrm{~g}$ of carbon fixed (about $3.6 \%$ of the estimated value).

\section{Net Flux of Phytoplankton}

The high levels of nitrogen and other nutrients in Flax Pond (Whitney et al., 1975) could readily stimulate phytoplankton production in Long Island Sound when ebb tides bring these nutrient-rich waters out of marsh systems. The final calculations made using the predictive equations implied an enhanced production in Long Island Sound by water coming out of the marshes on ebbing tides. This finding led us to reconsider the net exchange of phytoplankton between Flax Pond and Long Island Sound. Samples for chlorophyll biomass and cell counts were taken as a routine part of the net exchange sampling carried on by Brookhaven National Laboratory. Analysis of these samples showed a consistent and high influx of chlorophyll to Flax Pond with the tides (Fig. 6). Up to 0.1 gram of chlorophyll was lost per square meter of marsh covered by water at high tide on the exchange of one summer tide. This net loss of phytoplankton was supported, to a lesser extent, by measures of total particulate carbon exchanged with the tides (Woodwell et al., 1975).

\section{Heterotrophy in Flax Pond}

The net flux of chlorophyll (Fig. 6) as well as the measurements of $14 \mathrm{C}$ uptake within the marsh indicated that Flax Pond salt marsh was not a producer of phytoplankton. Preliminary measurements of benthic respiration in the marsh (Woodwell et al., 1975) showed high metabolic activity during warm weather. Readings of $\mathrm{pH}$ taken throughout the day in the marsh creeks and embayments showed $\mathrm{CO}_{2}$ build-up was sufficiently high to of ten require a half day of photosynthesis to offset (Fig. 7). However, the 
Table 3. Comparisons of different estimates of productivity in Flax Pond

\begin{tabular}{|c|c|c|c|c|c|c|}
\hline \multirow{2}{*}{$\begin{array}{l}\text { Conditions used } \\
\text { in prediction }\end{array}$} & \multicolumn{3}{|l|}{ Production in $\mathrm{g} \mathrm{C}$} & \multicolumn{3}{|c|}{ Percent increase over natural conditions } \\
\hline & VII. $1972-X .1973$ & VII. 1972-VII. 1973 & x. $1972-x .1973$ & VII. 1972-X. 1973 & VII. 1972-VIT. 1973 & x. 1972-x. 1973 \\
\hline Natural conditions & $8.078 \times 10^{6}$ & $5.608 \times 10^{6}$ & $5.871 \times 1.0^{6}$ & - & - & - \\
\hline A11 sunny days & $8.810 \times 10^{6}$ & $6.268 \times 10^{6}$ & $6.392 \times 10^{6}$ & 8.31 & 10.53 & 8.10 \\
\hline High tides at $12.00 \mathrm{hrs}$ & $8.198 \times 10^{6}$ & $5.807 \times 10^{6}$ & $5.885 \times 10^{6}$ & 1.46 & 3.42 & .13 \\
\hline $\begin{array}{l}\text { All sunny days and high } \\
\text { tides at } 12.00 \text { hrs }\end{array}$ & $8.895 \times 10^{6}$ & $6.428 \times 10^{6}$ & $6.389 \times 10^{6}$ & 9.18 & 12.76 & 8.01 \\
\hline $\begin{array}{l}15 \mathrm{~m} \text { of water, natural } \\
\text { conditions }\end{array}$ & $3.931 \times 10^{8}$ & $2.674 \times 10^{8}$ & $2.964 \times 10^{8}$ & 4766.30 & 4668.81 & 4948.97 \\
\hline $\begin{array}{l}15 \mathrm{~m} \text { of water, all } \\
\text { sunny days }\end{array}$ & $4.254 \times 10^{8}$ & $2.963 \times 10^{8}$ & $3.200 \times 10^{8}$ & 5166.53 & 5183.17 & 5350.25 \\
\hline
\end{tabular}

Table 4. Data from July 1973. The levels of 5 variables measured throughout the day on two dates show a larger range in $\mathrm{pH}, \mathrm{CO}_{2}$, and ${ }^{14} \mathrm{C}$ uptake on July $30 t h$. Because water temperature and sunlight levels were similar on both dates, differences were attributed to time of flood tide

\begin{tabular}{|c|c|c|c|c|c|}
\hline \multicolumn{6}{|l|}{ July 23,1973} \\
\hline Time & $09.14 \mathrm{hrs}$ & $11.13 \mathrm{hrs}$ & $14.04 \mathrm{hrs}$ & $15.43 \mathrm{hrs}$ & $17.29 \mathrm{hrs}$ \\
\hline $\mathrm{pH}$ & 7.98 & 8.13 & 7.83 & 8.14 & 8.13 \\
\hline $\mathrm{CO}_{2}(\mathrm{mg} / 1)$ & 17.26 & 20.16 & 21.20 & 20.05 & 19.89 \\
\hline water temperature $\left({ }^{\circ} \mathrm{C}\right)$ & 21.6 & 22.3 & 24.6 & 20.6 & 21.0 \\
\hline Sunlight $(\mathrm{g} \mathrm{cal} / \mathrm{min})$ & 0.68 & 1.24 & 1.34 & 1.12 & 0.69 \\
\hline${ }^{14} \mathrm{C}$ uptake $\left(\mathrm{mg} \mathrm{c} / \mathrm{m}^{3} / \mathrm{h}\right)$ & 57.2 & 75.5 & 34.9 & 69.0 & 48.0 \\
\hline \multicolumn{6}{|l|}{ July 30,1973} \\
\hline Time & $08.39 \mathrm{hrs}$ & $10.43 \mathrm{hrs}$ & $13.25 \mathrm{hrs}$ & $15.12 \mathrm{hrs}$ & $17.04 \mathrm{~h} x \mathrm{~s}$ \\
\hline $\mathrm{pH}$ & 7.63 & 7.88 & 8.21 & 8.22 & 7.91 \\
\hline $\mathrm{CO}_{2}(\mathrm{mg} / 1)$ & 23.82 & 22.57 & 20.64 & 20.76 & 22.69 \\
\hline Water temperature $\left({ }^{\circ} \mathrm{C}\right)$ & 22.2 & 22.7 & 22.6 & 23.8 & 27.0 \\
\hline Sunlight $(\mathrm{g} \mathrm{cal} / \mathrm{min})$ & 0.51 & 1.07 & 1.26 & 0.85 & 0.70 \\
\hline${ }^{14_{\mathrm{C}}}$ uptake $\left(\mathrm{mg} \mathrm{c} / \mathrm{m}^{3} / \mathrm{h}\right)$ & 142.0 & 47.0 & 44.0 & 29.6 & 8.2 \\
\hline
\end{tabular}

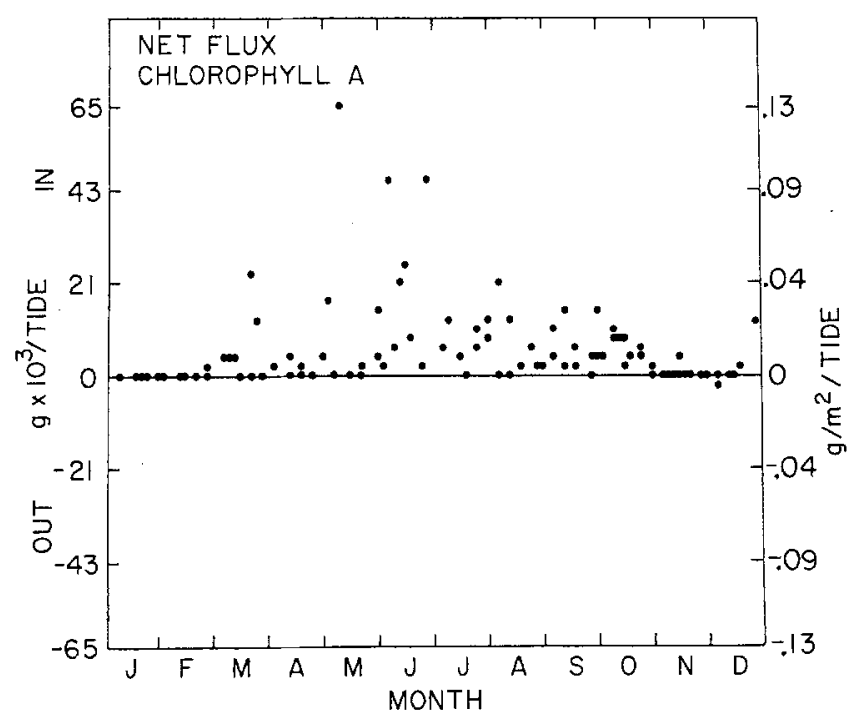

Fig. 6. Net flux of chlorophyll over course of the year. An inward flux is shown as a point above the zero line, an outward flux is a point below the zero line. Each point is weighted average (weighted by volume of flow of water into or out of marsh) of 8 samples taken throughout the course of one tide. Samples prodived by Brookhaven National Laboratory

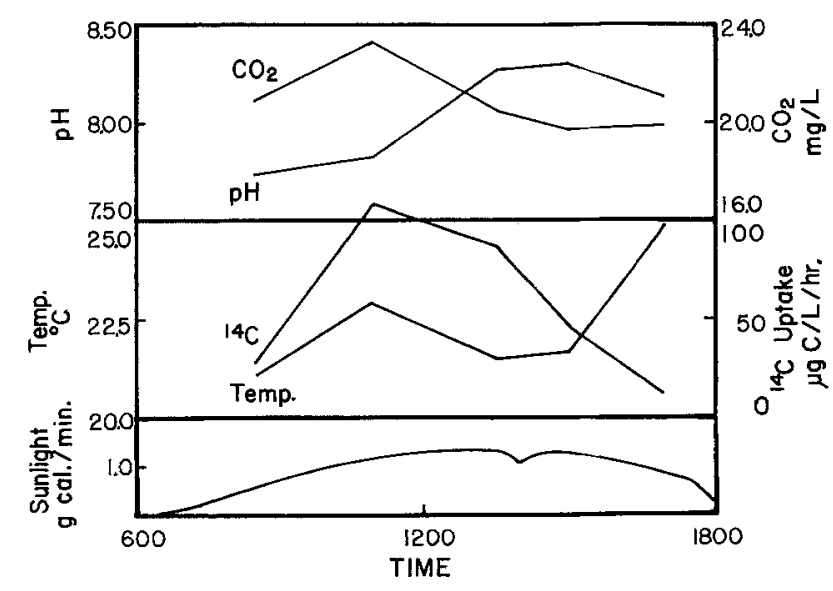

Fig. 7. Change in phytoplankton production and related variables between 07.00 and $18.00 \mathrm{hrs}$ on July 18, 1973 
interpolation of $\mathrm{pH}-\mathrm{CO}_{2}$ data from a shallow, tidal embayment was difficult. The $\mathrm{pH}, \mathrm{CO}_{2},{ }^{14} \mathrm{C}$, sunlight and temperature data from July 23 and 30, 1973 (Table 4), show the complexity of the metabolic activity of the marsh system. These data demonstrate that on two dates when ${ }^{14} \mathrm{C}$ uptake, temperature, and sunlight were comparable, $\mathrm{pH}$ values were very different; July 23 had a pH range of 0.31 units, while July 30 had a range of 0.59 units. The time of high tide (hour of day when fresh water was brought into the marsh), amount of respiration in the water, and benthic respiration apparently had an effect on the $\mathrm{pH}$ of marsh water. The complex nature of these results raised some doubts as to the applicability of using any type of free-water method (Odum, 1956; Hall, 1972) to predict primary production in a salt marsh. Any prediction of primary production using $\mathrm{pH}$ or oxygen would require deciphering the combined effects of time of tide, $\mathrm{pH}$ of incoming tidal waters, autotrophic production, and heterotrophic respiration within the marsh. These data suggest that freewater $\mathrm{pH}$ and/or oxygen measurements should only serve as a supplement to bottle methods, not as a replacement.

The ${ }^{14} \mathrm{C}$ uptake (Fig. 2), chlorophyll net flux (Fig. 6), and pH data (Fig. 7) indicated that phytoplankton within the marsh did not add considerably to the carbon pool of the marsh. The incoming tidal water, on the other hand, brought in a good supply of phytoplankton (measured as chlorophyll biomass), much of which was left in the ecosystem. The ultimate fate of the phytoplankton left in the marsh was not determined from this study, but simple speculation was possible. Any casual visit to a salt marsh system such as Flax Pond reveals the abundance of benthic filter-feeders (filter-feeding worms and shellfish; Hechtel, 1969). These filter-feeders could readily reduce the standing stock of phytoplankton in salt marsh waters, making these systems dependent on sources of primary production from another ecosystem (in this case Long Island sound). The possibility that the plankton could settle out of shallow, warm back-waters of the marsh at high tide cannot be neglected.

\section{Conclusions}

Flax Pond salt marsh has shown some interesting contrasts in terms of the importance of phytoplankton to marsh ecosystems. Productivity on a $\mathrm{mg} \mathrm{C} / \mathrm{m}^{3} / \mathrm{h}$ basis was quite high, evidently sup- ported by high levels of nutrients in the salt marsh. The initial impression was that production by phytoplankton within the marsh would add significantly to the carbon pool of Flax Pond. However, when the productivity values were reduced by the combined effect of high extinction coefficients and the shallow basin of water available for photosynthesis, the net production by phytoplankton in the marsh was small. Dividing the net production estimates by the number of square meters in the entire marsh system resulted in only $11.7 \mathrm{~g}$ carbon fixed by phytoplankton per square meter of marsh per year, a small fraction of normal near-shore production (Steele, 1974).

The relatively small amount of carbon fixed by phytoplankton in the salt marsh raised doubts as to the ability of the marsh to conform to the role of a net exporter of plant material, or at least phytoplankton (Odum, 1971; Day et al., 1973). Analysis of water exchanged between the salt marsh and the near-shore aquatic environment showed the salt marsh was a consistent and often large consumer of phytoplankton. However, the salt marsh may greatly stimulate phytoplankton production by releasing nutrient-rich water into the near-shore waters (Whitney et al.,1975). Once the nutrient-rich (particularly nitrogenenriched) water coming from Flax Pond reaches more open waters (Long Island Sound), there is sufficient light and depth of water to allow high rates of photosynthesis to develop.

The production and net flux of phytoplankton in Flax Pond did not appear to conform to the same scheme as has been observed in some of the southeastern United States salt marshes studied (Williams, 1966; Odum, 1971; Day et al., 1973). Whether this ecosystem is less productive than other salt marsh ecosystems because of climate, size, drainage basin, or location is as yet undetermined. Studies of other salt marshes, such as that of Nixon and Oviatt (1973), should reveal some underlying causes in the functioning of these ecosystems. However, for the time being we may have to reevaluate the role of phytoplankton in some salt marshes in terms of ecosystem structure and function.

Acknowledgements. I am greatly indebted to Dr. G.M. Woodwell for the use of the facilities at Brookhaven National Laboratory, and the use of data collected from Flax Pond. I would also like to thank Mr. N. Tempel who designed, built, and maintained most of the sampling gear used in the salt marsh, and who aided me through numer- 
ous mechanical failures. I would particularly like to thank Dr. E.R. Baylor of SUNY at Stony Brook, who provided invaluable and considerable advice on the form of this research. Thanks also go to Drs. F.J. Rohlf and G.C. Williams of SUNY at Stony Brook and P.H. Rich of the University of Connecticut for advice on the scope of this research. My sincerest thanks go to Dr. P. Moll for invaluable help in the data analysis and criticisms of this manuscript.

\section{Literature Cited}

Armentano, T.V. and G.M. Woodwell: Sedimentation rates in a Long Island marsh determined by $210 \mathrm{~Pb}$ dating. Iimnol. Oceanogr. 20, 452-455 (1975)

Day, J.W., W.G. Smith, P.R. Wagner and W.C. Stowe: Community structure and carbon budget. of a salt marsh and shallow bay estuarine system in Louisiana, $80 \mathrm{pp}$. Baton Rouge, La.: Center for Wetland Resources, Louisiana state University 1973 (Pul. No. LSU-SG-72-04)

Hall, C.A.S.: Migration and metabolism in a temperate stream ecosystem. Ecology 53, 585-604 (1972)

- and R.A. MoIl: The measurement of primary productivity in water. In: Primary productivity of the biosphere, pp 19-53. Ed. by H. Lieth and R. Whittaker. New York: Springer-Verlag 1975

Hechtel, G.: Invertebrate survey of Flax Pond summer 1976. Tech. Rep. N.Y. St. Univ. mar. Sci. Res. Cent. 1, 1-40 (1969)

Lewis, W.M.: Primary production in the plankton community of a tropical lake. Ecol. Monogr. $44,377-409$ (1974)

Li, J.C.R.: Statistical inference II, 575 p. Ann Arbor: Edwards Brothers, Inc. 1964

Moll, R.A.: The phytoplankton community of a temperate zone salt marsh, $122 \mathrm{p}$. Ph.D. dissertation, State University of New York at Stony Brook 1974

Nixon, S. and C. Oviatt: Ecology of a New England salt marsh. Ecol. Monogr. 43, 463-498 (1973)

Odum, E.: Fundamentals of ecology, 3rd ed. 574 pp. Philadelphia: W.B. Saunders Co. 1971

Odum, H.T.: Primary production of flowing waters. Limol. Oceanogr. 2, 85-97 (1956)

Qasim, S.Z., S. Wellerhaus, P.M.A. Bhattathiri and S.A.H. Abidi: Organic production in a tropical estuary. Proc. Indian Acad. Sci. (sect. B) 69, 51-94 (1969)

Ragotskie, R.: Plankton productivity in estuarine waters of Georgia. Publs Inst. mar. Sci. Univ. Tex. 6, 146-158 (1959)

Rich, P.H. and R. Wetzel: A simple, sensitive underwater photometer. Iimnol. Oceanogr. 14, $611-613$ (1969)
Riley, G.A.: Oceanography of Long Island Sound 1952-1956: IX. Production and utilization of organic matter. Bull. Bingham oceanogr. Coll. $15,324-343$ (1956)

Schelske, C.L. and E.P. Odum: Mechanisms maintaining high productivity in Georgia estuaries. Proc. Gulf Caribb. Fish. Inst. 14, $75-80$ (1961)

SCOR-UNESCO: Recommended procedures for measuring the productivity of plankton standing stock and related oceanic properties, $59 \mathrm{pp}$. Washington, D.C.: National Academy of Sciences 1969

Sokal, R.R. and F.J. Rohlf: Biometry, the principles and practices of statistics in biological research, 571 pp. San Francisco: W.H. Freeman \& Co. 1969

Steele, J.H.: The structure of marine ecosystems, 128 pp. Cambridge, Mass.: Harvara University Press 1974

Steemann Nielsen, E.: The use of radioactive carbon $\left({ }^{4} \mathrm{C}\right)$ for measuring organic production in the sea. J. Cons. perm. int. Explor. Mer 18, 117-140 (1952)

Strickland, J.D.H. and T.R. Parsons: A practical handbook of seawater analysis. Bull. Fish. Res. Bd Can. 167, 1-310 (1972)

Teal, J.M.: Energy flow in the salt marsh ecosystem of Georgia. Ecology 43, 614-624 (1962)

Whitney, D.E., G.M. Woodwell and R.W. Howarth: Nitrogen fixation in Flax Pond: a Long Island salt marsh. Iimnol. Oceanogr. 20, 640-644 (1975)

Williams, R.B.: Annual phytoplankton production in a system of shallow temperate estuaries. In: Some contemporary studies in marine science, pp 699-716. Ed. by H. Barnes. London: George Allen \& Unwin Ltd. 1966

Woodwell, G.M., C.A.S. Hall, D. Whitney, D.W. Juers and R.A. Moll: Material exchanges between Flax Pond marsh system and Long Island Sound. Presented at Third International Estuarine Research Conference, Galveston, Texas, 1975

- and E.V. Pecan: Flax Pond: an estuarine marsh. Publs Brookhaven natn. Lab. (BNL), N.Y. BNL $50397,1-7$ (1973)

-, P.H. Rich and C.A.S. Hall: Carbon in estuaries. In: Carbon and the biosphere, pp 221-240. Ed. by G.M. Woodwell and E.V. Pecan. Technical Information Center, office of Information Services, United States Atomic Energy Comission. 1973. (National Technical Information Service No. CONF-720510)

Russell A. Moll

Great Lakes Research Division IST Bldg., University of Michigan Ann Arbor, Michigan 48109 USA 